University of Wyoming College of Law

Law Archive of Wyoming Scholarship

6-18-2009

\title{
Judging by the Numbers: An Empirical Study of the Power of Story to Persuade (Test Briefs)
}

Kenneth D. Chestek

University of Wyoming College of Law, kchestek@uwyo.edu

Follow this and additional works at: https://scholarship.law.uwyo.edu/other

\section{Recommended Citation}

Chestek, Kenneth D., "Judging by the Numbers: An Empirical Study of the Power of Story to Persuade (Test Briefs)" (2009). Other Publications and Activities. 6.

https://scholarship.law.uwyo.edu/other/6

This Article is brought to you for free and open access by the UW College of Law Faculty Scholarship at Law Archive of Wyoming Scholarship. It has been accepted for inclusion in Other Publications and Activities by an authorized administrator of Law Archive of Wyoming Scholarship. 


\title{
JUDGING BY THE NUMBERS: AN EMPIRICAL STUdy OF THE POWER OF STORY
}

\author{
Test Briefs in BiggBox Lumber Co. v. Independence County
}

\author{
Kenneth D. Chestek \\ Clinical Professor of Law, Indiana University School of Law-Indianapolis
}

This document includes all four of the test briefs used in a study conducted from January through March, 2009. During this study, volunteer appellate judges, law clerks, appellate practitioners and law professors were asked to read two of these briefs (both on the same side of this fictional case) and then to report, via an anonymous online survey, which of the two briefs was more persuasive.

In each pair of briefs (the Petitioner pair and the Respondent pair), Brief 1 was designed as a "logos" brief, while Brief 2 was designed as a "storytelling" brief. For more information about how the study was designed and what its findings were, see the article "Judging By the Numbers: An Empirical Study of the Power of Story" (forthcoming on SSRN). 


\section{IN THE SUPREME COURT OF WeST DAKotA}

Biggbox Lumber Company,

Inc., a Delaware corporation,

Petitioner

vS.

Independence County, a

political subdivision of the State of West

Dakota, by and through Charles

White, in his capacity as District

Attorney of Independence County,

Respondents

No. 421 G.D. 2008

On Petition for Review from the Court of Appeals of

West Dakota, opinion dated June 2, 2008, at

No. 802 of 2008

\section{Brief One for Petitioner}

Submitted by:

Attorney One, Esq.

314 Main Street

Old Orleans, W.D.

Counsel for Petitioner, BiggBox Lumber

Inc. 


\section{Table of Contents}

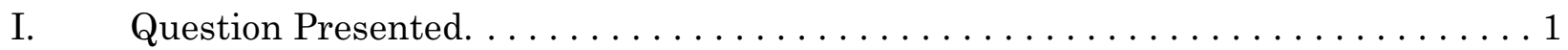

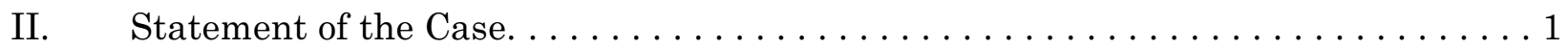

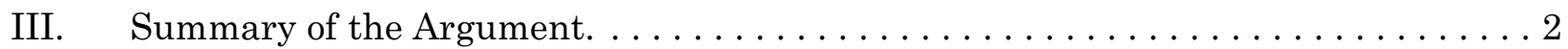

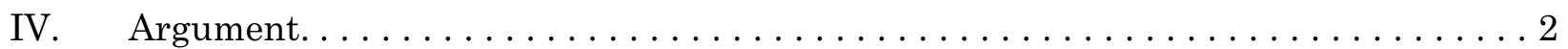

A. Long-standing precedent grants free speech rights to corporations... . . . . 3

B. No reason exists to depart from precedent in this case. . . . . . . . . . 4

1. This Court has no authority to overturn United States Supreme Court

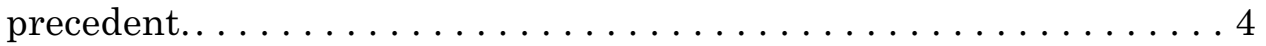

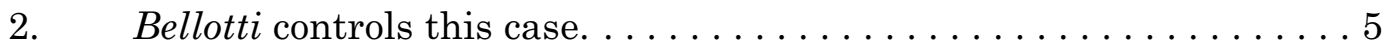

3. The West Dakota Constitution also protects corporations. . . . . . 6

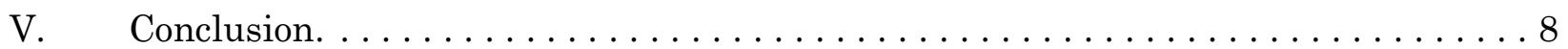




\section{Table of Authorities}

\section{Constitutional Provisions}

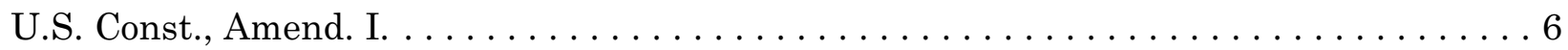

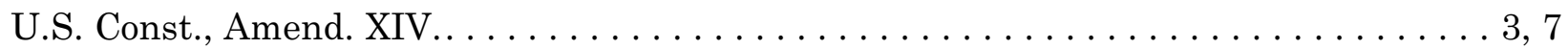

U.S. Const., Art. VI, cl. $2 \ldots \ldots \ldots \ldots \ldots \ldots \ldots \ldots \ldots \ldots \ldots \ldots \ldots \ldots \ldots \ldots \ldots \ldots \ldots$

West Dakota Constitution, Art. I, $\S 1 \ldots \ldots \ldots \ldots \ldots \ldots \ldots \ldots \ldots \ldots \ldots \ldots \ldots$

\section{Cases}

Azalia Enterprises, Inc. v. Porter, 218 W.D. $12(1936) \ldots \ldots \ldots \ldots \ldots \ldots \ldots \ldots \ldots \ldots \ldots$

Berwyn Motor Company, Inc. v. Board of Assessment Appeals, 519 W.D. 712 (1971). . . . 7

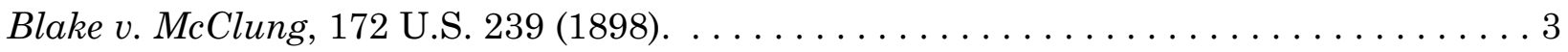

Brock v. Roundtree Associates, Inc., 457 W.D. 192 (1968). . . . . . . . . . . . . . . . 7

Bullard Industries $v$. Smith, 421 W.D. $461(1964) \ldots \ldots \ldots \ldots \ldots \ldots \ldots \ldots \ldots$

Citizens Against Rent Control v. City of Berkeley, 454 U.S. 290 (1981).. . . . . . . . . . . 3

Covington \& L. Turnpike Road Co. v. Sandford, 164 U.S. 578 (1896). . . . . . . . . . . . 3

First National Bank of Boston v. Bellotti, 435 U.S. 765 (1978) . . . . . . . . . . . 3-6

Kentucky Finance Corp. v. Paramount Auto Exchange Corp., 262 U.S. 544 (1923). . . . . . 3

Kronos Timepieces, Inc. v. Serafin, 451 W.D. $469(1962) \ldots \ldots \ldots \ldots \ldots \ldots \ldots \ldots$

Pennekamp v. Florida, 328 U.S. $331(1946) \ldots \ldots \ldots \ldots \ldots \ldots \ldots \ldots \ldots \ldots$

Santa Clara Co. v. Southern Pac. Ry. Co., 118 U. S. 394 (1886). . . . . . . . . . . . . 3, 4

Wheeling Steel Corp. v. Glander, 337 U.S. 562, 574 (1949). . . . . . . . . . . . . . . 3 


\section{Question Presented}

The question certified by this Court is as follows: "Whether Proposition 3, adopted by the voters of Independence County, unconstitutionally deprives corporations of protectable rights under either the First Amendment to the United States Constitution or Article $1, \S 6$ of the West Dakota Constitution.”

\section{Statement of the Case}

In November 2003, the voters of Independence County, West Dakota, adopted Proposition 3. Section 5 of that initiative purports to prohibit "non-local corporations" from using corporate funds to, among other things, "[i]nfluenc[e] public opinion in an effort to promote or defeat any ordinance, resolution, or initiative, or any amendment thereto, under consideration by Independence County or any local government unit within Independence County ....".

The Petitioner, BiggBox Lumber Company, Inc. ("BiggBox"), has filed the proper registration statement necessary to do business in West Dakota. In early 2007, Biggbox acquired an option to purchase 100 acres of vacant land in Wetmarsh Township, Independence County, near the interchange of Highway 81 and County Road BB. It then petitioned the township supervisors for a rezoning of that tract to C-1 Commercial to allow it to build a BiggBox SuperCenter retail store. On August 1, 2007, BiggBox took out a fullpage ad in the Old Orleans Gazette, urging citizens of Wetmarsh Township to write to their supervisors to support the zoning change.

On August 21, 2007, the township supervisors rejected the rezoning request, and

sent a letter to the Independence County District Attorney, claiming that BiggBox's ad in the Old Orleans Gazette violated Proposition 3. The District Attorney then brought this lawsuit seeking to impose a fine of $\$ 20,120$ (ten times the cost of the advertisement), pursuant to Section 11 of Proposition 11. BiggBox moved to dismiss the Complaint on numerous grounds, including a claim that Proposition 3 was an unconstitutional violation of BiggBox's right of free speech. 
The Superior Court of Independence County ruled on November 12, 2007 that Proposition 3 violated the First Amendment to the United States Constitution, and dismissed the Complaint without addressing BiggBox's other claims. On appeal the Court of Appeals of West Dakota reversed and remanded the case for consideration of BiggBox's other claims. BiggBox petitioned this Court for review of the ruling by the court below, which this Court granted on July 28, 2008, limited to the issue specified above.

\section{Summary of the Argument}

Long-standing precedent of both the United States Supreme Court and of this Court holds that corporations are "persons" entitled to the protections of the Fourteenth Amendment to the United States Constitution. Since the First Amendment is applicable to the states through the Fourteenth Amendment, this means that corporations enjoy the right to freedom of speech just as natural persons do.

No reason exists to depart from this long-standing precedent. This Court is bound by the rulings of the United States Supreme Court on matters of interpretations of the First Amendment, and that court has squarely ruled in First National Bank v. Bellotti that corporations enjoy the right of free speech, especially when that speech pertains to matters of public interest (such as a zoning dispute). This case is indistinguishable from Bellotti.

The West Dakota Constitution does not provide an alternative ground for decision in this case, since its provisions must be interpreted consistently with the United States Constitution as to matters involving freedom of speech. Interpreting the West Dakota Constitution in such a way as to deprive corporations of their freedom of speech would deny them the right to protect their property interests, which would violate the Fourteenth Amendment.

\section{Argument}

Both the First Amendment to the United States Constitution and the free speech provisions of the West Dakota Constitution have long been held to protect corporate speech. Respondents do not seriously contend otherwise. This case requires only that this 
Court decide whether it should depart from that long-standing precedent. Since the principle of corporate free speech has served the marketplace well, there is no justification for this Court to depart from that principle in this case.

\section{A. Long-standing precedent grants free speech rights to corporations}

The Fourteenth Amendment to the United States Constitution has long been interpreted to extend property rights to corporations. In Santa Clara Co. v. Southern Pac. Ry. Co., 118 U. S. 394 (1886), the Court was faced with the issue of whether local taxes had been properly levied on fences owned by several railroad companies. At oral argument, the Court indicated that it did not want to hear argument on the question of whether the railroad corporations were "persons" for the purpose of the Equal Protection Clause, stating that it was of the unanimous opinion that the clause did protect those corporations. Id. at 396 .

Numerous Supreme Court cases since the Santa Clara case have held that corporations are "persons" entitled to the protection of the Fourteenth Amendment. See, e.g., Covington \& L. Turnpike Road Co. v. Sandford, 164 U.S. 578 (1896); Blake v. McClung, 172 U.S. 239 (1898); Kentucky Finance Corp. v. Paramount Auto Exchange Corp., 262 U.S. 544 (1923); Wheeling Steel Corp. v. Glander, 337 U.S. 562, 574 (1949) (Jackson, J., concurring) (explaining why the majority opinion assumed without discussion that corporations are persons entitled to 14th Amendment protection). This Court has likewise held that corporations are entitled to the protections of the equal protection provisions of the West Dakota Constitution. Kronos Timepieces, Inc. v. Serafin, 451 W.D. 469 (1962).

The Supreme Court has also held that corporations are "persons" for the purpose of First Amendment analysis, at least for the protection of "core" speech on matters of public interest and policy. In First National Bank of Boston v. Bellotti, 435 U.S. 765 (1978), a Massachusetts statute attempted to prohibit corporations from "making contributions or expenditures 'for the purpose of . . . influencing or affecting the vote on any question submitted to the voters, other than one materially affecting any of the property, business or assets of the corporation." Holding that the statute restricted speech on matters involving governmental affairs, the Court held that the statute "abridge[d] expression that 
the First Amendment was meant to protect." Id. at 776. Cf. Citizens Against Rent Control v. City of Berkeley, 454 U.S. 290 (1981) (holding that an ordinance adopted by voters which attempted to limit contributions to committees formed to support or oppose ballot measures to $\$ 250$ violated First Amendment right of free speech).

Proposition 3 attempts to eliminate the ability of "non-local corporations" (including BiggBox) from speaking out on matters involving governmental affairs, in exactly the same way that the Massachusetts statute in Bellotti did. It therefore violates the First Amendment to the United States Constitution.

\section{B. No reason exists to depart from precedent in this case}

In the court below, Independence County did not substantively contest the proposition that the Supreme Court of the United States, in numerous cases, has held that corporations are entitled to constitutional protection of their property rights, including the freedom to speak to governmental officials about those rights. Rather, the County argued (and the court below agreed) that those precedents should now be overruled; that this case fits within a narrow exception contemplated by the Court in the Bellotti case; or that this case should be decided upon some alternative West Dakota constitutional ground. None of these claims suffice.

\section{This Court has no authority to overturn United States Supreme Court precedent}

The most obvious defect in the County's position is, of course, that this Court lacks authority to overrule the United States Supreme Court. The U.S. Constitution is "the supreme Law of the Land; and the Judges in every State shall be bound thereby, any Thing in the Constitution or Laws of any State to the Contrary notwithstanding." U.S. Const., Art. VI, cl. 2. The United States Supreme Court is the final arbiter of the meaning of the United States Constitution, and its decisions are binding on all state courts. Pennekamp $v$. Florida, 328 U.S. 331 (1946).

The County's position that corporate personhood should be abolished proceeds from the premise that the language regarding corporate rights in the Santa Clara case is found only in the syllabus of the court reporter, and not in the opinion of the Court itself. Were 
the Santa Clara case the only one which claimed that corporations are entitled to the protection of the Fourteenth Amendment, the County's argument might have arguable merit. However, the County's argument does not account for the fact that many subsequent opinions of the Supreme Court (several of which are cited above) have in fact included, within the opinion of the Court itself, holdings that corporations are entitled to the protection of the Fourteenth Amendment. See cases cited at p. 3, supra. This Court simply lacks the authority to overrule that long line of cases.

\section{Bellotti controls this case}

The County argued, and the Court below agreed, that the Bellotti case did not control the decision in this case. However, Bellotti is directly on point, and requires this Court to reverse the Court of Appeals.

Bellotti involved a situation very similar to that posed by this case. A Massachusetts statute prohibited corporations from making contributions or expenditures to influence public opinion on matters to be submitted to them for referendum. The United States Supreme Court held that the First Amendment protected speech, not speakers, so the corporate nature of the speaker was irrelevant. Bellotti, 435 U.S. at 777. The Court did not hold that corporate speakers were entirely free from government interference; rather, it held that restraints on corporate speech must be subjected to "exacting scrutiny," and can be upheld only by a showing of a "compelling interest" in restraining the speech. Id. at 786 . The court held that "[p]reserving the integrity of the electoral process, preventing corruption, and 'sustain[ing] the active, alert responsibility of the individual citizen in a democracy for the wise conduct of government' are interests of the highest importance. . . . Preservation of the individual citizen's confidence in government is equally important." Id. at 788-89. The court said in dicta that if there had been evidence in the record or "legislative findings that corporate advocacy threatened imminently to undermine democratic processes, thereby denigrating rather than serving First Amendment interests," then the restrictions imposed by the Massachusetts legislation would have merited the Court's consideration. Id. at 789. But since there had been "no showing that the relative voice of corporations has been overwhelming or even significant in influencing referenda in Massachusetts, or that there has been any threat to the confidence of the 
citizenry in government," $i d$. at 789-90, the court could not find that the Massachusetts statute met the standard.

The court below found that Proposition 3 did include specific legislative findings

that "threatened imminently to undermine democratic processes." Indeed, Section 3 includes a list of specific legislative findings, one of which uses the precise language of the Bellotti case in finding that "non-local corporate contributions are undermining our democratic processes, creating the appearance of impropriety and corruption, and are causing the people of Independence County to lose confidence in the integrity of our elections and in our government." Proposition 3, Section 3, paragraph 7 (emphasis supplied; see also similar language at the end of paragraph 8). The italicized words of this quote appear to be an attempt to take advantage of the limited exception noted in the majority opinion of Bellotti. Thus, these words more likely reflect clever draftsmanship than sincere findings of fact.

Corporate speech has a long history of protection under the First Amendment.

"Citizens" are accustomed to hearing corporate speech on a daily basis, and can be trusted to make their own judgments as to the merits of such speech. The "findings" put before the Independence County voters in Proposition 3 are stated in general terms and suggest no evidence of how citizens' "confidence in their government" has been undermined in any way by commonplace corporate speech. Therefore, this case does not fall within the limited exception discussed in Bellotti.

\section{The West Dakota Constitution also protects corporations}

The County also argued, and the court below agreed, that an alternative ground for decision exists under Article I, section 1 of the West Dakota Constitution; specifically, that only humans have the right to form governments, and therefore implicitly only humans have a right to seek to influence governmental decisions. However, this argument relies on an interpretation of the word "people" that is contradicted by prior decisions of this Court; moreover, such an interpretation would deprive corporations of one remedy for violations of their well-established rights.

The West Dakota Constitutional provision that the County relies on states: 
We the People declare that all People are created equal; that they are endowed by their Creator with certain inalienable rights; that among these are life, liberty, and the pursuit of happiness; that all power is inherent in the People; and that all free governments are, and of right ought to be, founded on their authority, and instituted for their peace, safety, and well-being. For the advancement of these ends, the People have, at all times, an indefeasible right to alter and reform their government.

West Dakota Const., Art. I, § 1. The County contends that only humans can enjoy "life, liberty, and the pursuit of happiness," and that therefore only humans have the "right to alter and reform their government."

However, the words "persons" and "people" are synonyms. Roget's Online Thesaurus, http://thesaurus.reference.com/browse/people. This Court has, on many occasions, endorsed the legal fiction that corporations have the legal status of "persons" in a wide variety of contexts: the right to own property, Brock v. Roundtree Associates, Inc., 457 W.D. 192 (1968); the capacity to enter into contracts, and to sue and be sued, Azalia Enterprises, Inc. v. Porter, 218 W.D. 12 (1936); and, most importantly for the purposes of this case, the right to freedom of speech. Bullard Industries v. Smith, 421 W.D. 461 (1964). Governments have the power to regulate or significantly alter all of these rights. Depriving corporations of the right to speak out and of the opportunity to influence the governmental leaders who wield this power would render these rights virtually nonexistent, for a right without a remedy is no right at all. See, e.g., Berwyn Motor Company, Inc. v. Board of Assessment Appeals, 519 W.D. 712 (1971) ("under fundamental legal principles, a statute may not be construed as creating a right without a remedy"). Moreover, as established previously, the United States Supreme Court has frequently held that corporations are "persons" within the meaning of the Fourteenth Amendment's Equal Protection Clause. See discussion at p. 3, supra. Denying corporations the right to speak out in defense of their property interests would directly offend the Fourteenth Amendment. 
Since adopting the County's interpretation of Article I, § 1 would effectively deny corporations of the remedy of speaking with elected officials regarding their legal rights, that interpretation must be rejected by this Court.

\section{Conclusion}

Longstanding precedent of both this Court and the United States Supreme Court establish that corporations are entitled to protection of their property and free speech rights. This Court is powerless to overturn United States Supreme Court decisions, and no sufficient reason has been advanced for it to overturn its own decisions on this point. The Bellotti case, on facts legally indistinguishable from the case at bar, holds that attempts to muzzle corporate speech violate the First Amendment. The County's interpretation of the West Dakota Constitution would render the property and free-speech rights of corporations a virtual nullity by depriving corporations of one of their principle remedies for the violation of those rights by government officials. Accordingly, this Court should reverse the decision by the Court of Appeals, reinstate the decision of the Superior Court of Independence County, and dismiss this action.

Respectfully submitted

$/ \mathrm{s} /$ Attorney One

Attorney One, Esq.

314 Main Street

Old Orleans, W.D.

Counsel for Petitioner, BiggBox Lumber

Inc. 


\section{In The SuPREMe CoURT OF WeST DAKota}

Biggbox Lumber Company,

Inc., a Delaware corporation,

Petitioner

vS.

Independence County, a

political subdivision of the State of West

Dakota, by and through Charles

White, in his capacity as District

Attorney of Independence County,

Respondents

No. 421 G.D. 2008

On Petition for Review from the Court of Appeals of

West Dakota, opinion dated June 2, 2008, at

No. 802 of 2008

Brief Two for Petitioner

Submitted by:

Attorney Two, Esq.

413 Main Street

Old Orleans, W.D.

Counsel for Petitioner, BiggBox Lumber

Inc. 


\section{Table of Contents}

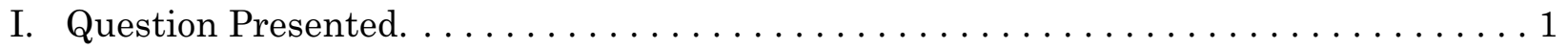

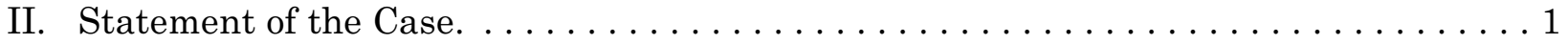

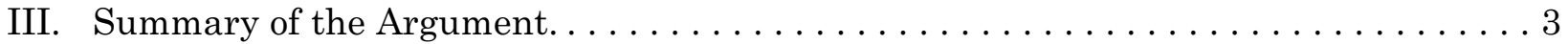

IV. Argument.................................. 3

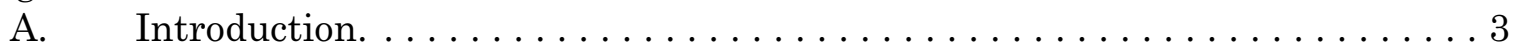

B. Settled precedent establishes that corporations enjoy the right of free speech4

C. No reason exists that suggests this Court should depart from its own precedent or that of the United States Supreme Court. . . . . . . . . . 6

D. The "self determination" provisions of the West Dakota Constitution do not conflict with corporate free speech rights. . . . . . . . . . . . 8

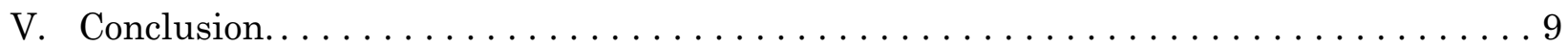




\section{Table of Authorities}

\section{Constitutional Provisions}

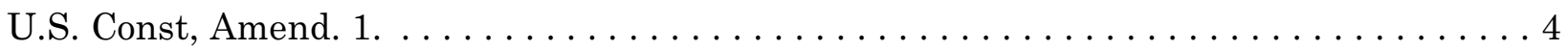

West Dakota Constitution of 1902, Article I, $\S 1$ (repealed) . . . . . . . . . . . 8

West Dakota Constitution, Article I, $\S 1 . \ldots \ldots \ldots \ldots \ldots \ldots \ldots \ldots \ldots \ldots \ldots$

\section{Cases}

44 Liquormart $v$. Rhode Island, 517 U.S. $484(1996) \ldots \ldots \ldots \ldots \ldots \ldots$

Beam v. Northmoor Community Hospital, 356 W.D. 152 (1962). . . . . . . . . . . . . . 7

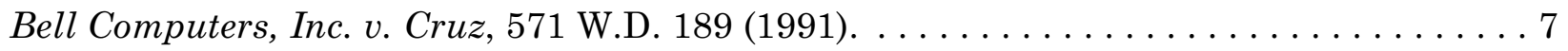

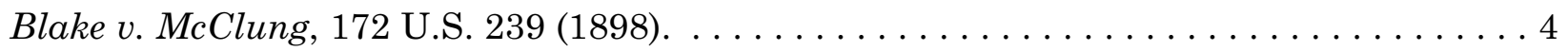

Citizens Against Rent Control v. City of Berkeley, 454 U.S. 290 (1981).. . . . . . . . . . 6

Covington \& L. Turnpike Road Co. v. Sandford, 164 U.S. 578 (1896). . . . . . . . . . . 4

F.T.C. v. Ticor Title Ins. Co., 504 U.S. $621(1992) \ldots \ldots \ldots \ldots \ldots \ldots \ldots \ldots \ldots$

First National Bank of Boston v. Bellotti, 435 U.S. 765 (1978) . . . . . . . . . . . 4, 5

Kentucky Finance Corp. v. Paramount Auto Exchange Corp., 262 U.S. 544 (1923). . . . . . . 4

Kriske v. Hodge, 349 W.D. $384(1961) \ldots \ldots \ldots \ldots \ldots \ldots \ldots \ldots \ldots \ldots \ldots \ldots$

Kronos Timepieces, Inc. $v$. Serafin, 451 W.D. $469(1962) \ldots \ldots \ldots \ldots \ldots \ldots \ldots \ldots \ldots \ldots \ldots, 7$

Laxney v. Hoover Community Schools, 448 W.D. 39 (1971).. . . . . . . . . . . . . . . . . 7

Mills v. Alabama, 384 U.S. $214(1966) \ldots \ldots \ldots \ldots \ldots \ldots \ldots \ldots \ldots \ldots \ldots$

Santa Clara Co. v. Southern Pac. Ry. Co., 118 U. S. 394 (1886). . . . . . . . . . . 4, 7, 8

United States. v. Topco Associates, Inc., 405 U.S. 596 (1972). . . . . . . . . . . . . . . 3

Wheeling Steel Corp. v. Glander, 337 U.S. $562(1949) \ldots \ldots \ldots \ldots \ldots \ldots \ldots \ldots \ldots$

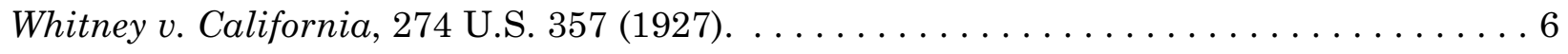




\section{Question Presented}

The question certified by this Court is as follows: "Whether Proposition 3, adopted by the voters of Independence County, unconstitutionally deprives corporations of protectable rights under either the First Amendment to the United States Constitution or Article $1, \S 6$ of the West Dakota Constitution.”

\section{Statement of the Case}

BiggBox Lumber Co., Inc., is the nation's fourth largest retail outlet for hardware and home improvement supplies. Its business model is to locate primarily in smaller communities which are not served by either of the two largest companies, Home Depot and Lowe's. In order to remain price competitive in the home improvement market, its operating margins are somewhat smaller than those of its larger competitors.

BiggBox operates three stores in West Dakota, and has filed all of the necessary registration statements to allow it to do business within the state. Early in 2007, BiggBox identified Old Orleans and the Lost River Valley area of West Dakota as a market not served by either Home Depot or Lowe's, but large enough to support a BiggBox retail store. It conducted a market study and determined that the best location for a new store would be a vacant parcel of land near the interchange of Highway 81 and County Road BB, several miles outside of the town of Old Orleans. It chose that location because its store would be visible from Highway 81, which is the main route in to the Lost River Recreation Area. The fact that the land was relatively flat and undeveloped would also reduce the cost of improving the land so as to support a standard BiggBox retail outlet.

BiggBox thereafter obtained an option to purchase the land, subject to the approval of the Wetmarsh Township Supervisors to rezone the land from agricultural to commercial. However, soon after BiggBox filed its rezoning application, representatives of the Old Orleans Area Industrial Development Agency contacted BiggBox, seeking to persuade BiggBox to abandon the Wetmarsh Township location and locate, instead, in a vacant sawmill within the Borough of Old Orleans. It offered various tax and financing incentives 
in order to encourage BiggBox to locate in the borough. BiggBox considered the Agency's proposal but ultimately rejected it, because it would have increased the cost of development of the store and because the location in the Borough of Old Orleans was not as visible nor as easily accessible from major thoroughfares.

After BiggBox rejected the overture from the Agency, it became apparent that representatives of the Agency were lobbying the Wetmarsh Township Board of Supervisors to reject the rezoning request, probably in order to gain leverage to renew the Agency's effort to convince BiggBox to locate within the borough. BiggBox then decided it needed to be proactive in seeking the rezoning. It purchased a full-page ad in the Old Orleans Gazette, the area's weekly newspaper, urging Wetmarsh Township residents to communicate to the Board of Supervisors their support of the rezoning so that BiggBox could locate in the community. The ad also emphasized that the store would bring to the region numerous new jobs as well as easy access to low-priced home improvement products. However, on August 21, 2007, the township supervisors rejected the rezoning application by a vote of $2-1$.

The supervisors also voted at that meeting to notify the Independence County District Attorney that, in their opinion, the Old Orleans Gazette advertisement violated Proposition 3, an ordinance adopted by the voters of Independence County in 2003 which purports to prohibit "non-local corporations" from using corporate funds to, among other things, "[i]nfluenc[e] public opinion in an effort to promote or defeat any ordinance, resolution, or initiative, or any amendment thereto, under consideration by Independence County or any local government unit within Independence County ....". The District Attorney agreed with the supervisors, and brought this lawsuit seeking to impose a fine of $\$ 20,120$ (ten times the cost of the advertisement), pursuant to Section 11 of Proposition 11. BiggBox moved to dismiss the Complaint on numerous grounds, including a claim that Proposition 3 was an unconstitutional violation of BiggBox's right of free speech.

The Superior Court of Independence County ruled on November 12, 2007 that Proposition 3 violated the First Amendment to the United States Constitution, and dismissed the Complaint without addressing BiggBox's other claims. On appeal the Court of Appeals of West Dakota reversed and remanded the case for consideration of BiggBox's 
other claims. BiggBox petitioned this Court for review of the ruling by the court below, which this Court granted on July 28, 2008, limited to the issue specified above.

\section{Summary of the Argument}

The prosperity that every American citizen enjoys is built upon the free enterprise system. That system requires an open marketplace not only for goods and services, but for ideas. Corporations, which have created a great deal of the wealth that our citizens enjoy, must have the right to participate freely in the marketplace of ideas to the same extent they are permitted to participate in the marketplace of commerce.

Long-standing precedent from the United States Supreme Court and this Court hold that corporations are entitled to freedom of speech as to matters of public interest, such as the current zoning dispute. While courts may, on rare occasions, depart from settled precedent in order to conform the common law to changed circumstances in modern society, the record is devoid of any evidence that society has changed in any material way since the doctrine of corporate personhood was first announced more than 100 years ago.

The West Dakota Constitution must also be interpreted consistently with the First Amendment of the United States Constitution. Both at the time of the original West Dakota Constitution in 1902, and the time of its substantial revision in 1952, the doctrine of corporate personhood was well-established and understood. Nothing in the text of either Constitution is inconsistent with the doctrine of corporate personhood.

\section{Argument}

\section{A. Introduction}

The free enterprise system has been described by the Supreme Court as "essential to economic freedom." F.T.C. v. Ticor Title Ins. Co., 504 U.S. 621, 632 (1992). "[T]he freedom guaranteed each and every business, no matter how small, is the freedom to compete- to assert with vigor, imagination, devotion, and ingenuity whatever economic muscle it can muster.” United States. v. Topco Associates, Inc., 405 U.S. 596, 610 (1972). 
While both of the cases cited above arose in the context of antitrust litigation, they reflect the common understanding that this nation has been built through economic freedom and vigorous free-market competition. But the voters of Independence County, West Dakota, think they have a better way of protecting their freedom: excluding from the public square the voices of the very businesses which have created much of the wealth and prosperity those voters now enjoy.

Fortunately, both the First Amendment to the United States Constitution and the similar provision of the West Dakota Constitution preclude that censorship. The free market requires freedom of speech for all participants, and this Court, as well as the United States Supreme Court, has long recognized this.

Precedent requires this Court to reverse the Court of Appeals. None of the justifications advanced by that court for declining to follow mandatory precedent are sufficient.

\section{B. Settled precedent establishes that corporations enjoy the right of free speech}

For more than 120 years, the United States Supreme Court has recognized that the Constitution protects corporate property rights on an equal basis with the rights of individuals. This principle was first announced in Santa Clara Co. v. Southern Pac. Ry. Co., 118 U. S. 394 (1886), and has been followed in a long line of cases since then. See, e.g., Covington \& L. Turnpike Road Co. v. Sandford, 164 U.S. 578 (1896); Blake v. McClung, 172 U.S. 239 (1898); Kentucky Finance Corp. v. Paramount Auto Exchange Corp., 262 U.S. 544 (1923); Wheeling Steel Corp. v. Glander, 337 U.S. 562, 574 (1949) (Jackson, J., concurring). This Court has likewise held that corporations are entitled to the protections of the equal protection provisions of the West Dakota Constitution. Kronos Timepieces, Inc. v. Serafin, 451 W.D. 469 (1962).

In light of the above, the Supreme Court has specifically held that corporate speech is entitled to First Amendment protection. In First National Bank of Boston v. Bellotti, 435 U.S. 765 (1978), a Massachusetts statute attempted to prohibit corporations from "making 
contributions or expenditures 'for the purpose of ... influencing or affecting the vote on any question submitted to the voters, other than one materially affecting any of the property, business or assets of the corporation." The Court noted that it had previously held that "a major purpose of the First Amendment was to protect the free discussion of governmental affairs.” Id. at 776-777 (quoting Mills v. Alabama, 384 U.S. 214, 218 (1966)). The Court wrote:

If the speakers here were not corporations, no one would suggest that the

State could silence their proposed speech. It is the type of speech indispensable to decisionmaking in a democracy, and this is no less true because the speech comes from a corporation rather than an individual. The inherent worth of the speech in terms of its capacity for informing the public does not depend upon the identity of its source, whether corporation, association, union, or individual.

Id. at 777 (footnotes omitted). The Court ultimately held that the Massachussetts statute "abridge[d] expression that the First Amendment was meant to protect." Id. at 776.

In the court below, the County argued that Belotti was distinguishable based upon some dicta included in the majority opinion. In Bellotti, Justice Powell wrote that if there had been evidence in the record or "legislative findings that corporate advocacy threatened imminently to undermine democratic processes, thereby denigrating rather than serving First Amendment interests," then the restrictions imposed by the Massachusetts legislation would have merited the Court's consideration. Id. at 789. But since there had been "no showing that the relative voice of corporations has been overwhelming or even significant in influencing referenda in Massachusetts, or that there has been any threat to the confidence of the citizenry in government," id. at 789-90, the majority could not find that the Massachusetts statute should be sustained as serving those interests.

The evidence in this case shows that Proposition 3 was drafted primarily by a group of attorneys affiliated with the advocacy group Save Our Forest Trees. It is therefore not surprising that the dicta from Belotti echoes throughout Section 3 of Proposition 3. That section includes a list of specific legislative findings, one of which uses the precise language of the Bellotti case in finding that "non-local corporate contributions are undermining our democratic processes, creating the appearance of impropriety and corruption, and are 
causing the people of Independence County to lose confidence in the integrity of our elections and in our government." Proposition 3, Section 3, paragraph 7 (emphasis supplied; see also similar language at the end of paragraph 8). But simply putting these words on paper does not make them true. Just as in Bellotti, the record in this case is devoid of evidence that such a loss of confidence actually exists. Bellotti is thus indistinguishable.

Had the chief executive officer of BiggBox taken out the very same ad in the Old Orleans Gazette that the corporation did, the ad would not have violated Independence County's Proposition 3, since that measure only prohibits corporations from participating in public discussions. See Proposition $3, \S 8$. Now, simply because the corporation paid for the ad instead of the CEO, the District Attorney is seeking to impose a financial penalty in the amount of ten times the cost of the ad. Since an individual could have legally purchased this ad, penalizing the corporation for doing so simply elevates form over substance. Cf. Citizens Against Rent Control v. City of Berkeley, 454 U.S. 290 (1981) (holding that an ordinance adopted by voters which attempted to limit contributions to committees formed to support or oppose ballot measures to $\$ 250$ violates First Amendments right of free speech and freedom of association, in part because the measure only placed contribution limits on associations and not on individuals).

BiggBox seeks nothing other than a level playing field in this case. The local citizens, including the officers of the Old Orleans Area Industrial Development Agency (itself a corporation, albeit a "local" one), were free to express their opinions to the Wetmarsh Township Board of Supervisors on this issue. Proposition 3, which attempts to prevent BiggBox from engaging in counterspeech on the very same issue, offends the basic notion that the proper remedy for "bad speech" is more speech. Whitney $v$. California, 274 U.S. 357, 377 (1927) (Brandeis, concurring); 44 Liquormart v. Rhode Island, 517 U.S. 484, 497 (1996) (applying Justice Brandeis' principle in the context of commercial speech). The free market requires nothing less than equal access to the public square for the purpose of discussing matters of economic interest to the entire community.

Accordingly, Proposition 3 offends the First Amendment to the United States Constitution, and must be struck down. 


\section{No reason exists that suggests this Court should depart from its own precedent or that of the United States Supreme Court}

While courts of last resort do have the authority to overrule prior decisions, such a remedy should be very rarely invoked. Indeed, as this court said many years ago:

In a Constitutional republican form of Government such as ours, which is based upon law and order, certainty and stability are essential. Unless the Courts establish and maintain certainty and stability in the law, businessmen cannot safely and wisely make contracts with their employees or with each other; ...

Beam v. Northmoor Community Hospital, 356 W.D. 152, 156 (1962) (rejecting an invitation to overrule the employment-at-will doctrine).

The County does not seriously dispute that current precedent protects the right of corporations to free speech. Rather, the County's principle argument appears to be that that long-settled principle should now be abandoned.

Corporations (like BiggBox) operating legally in Independence County enjoy the protection of both the United States and West Dakota constitutions. The United States Supreme Court has held since 1886 that corporations are entitled to $14^{\text {th }}$ Amendment protection. Santa Clara, 118 U.S. at 394. The Court has consistently followed that precedent ever since. See cases cited at p. 4, supra. This Court's own rulings which recognize that corporations are entitled to protection under the West Dakota Constitution also cite Santa Clara and its progeny. See, e.g., Kronos, 451 W.D. at 472; Bell Computers, Inc. v. Cruz, 571 W.D. 189 (1991). Thus, in order to prevail, the County must convince this Court that its previous reliance on Santa Clara was mistaken, or that this Court should now depart from a principle of law that protects the property rights of corporations, and thereby supports the free and open market that the citizens of Independence County now enjoy.

It is true that, when society has changed significantly and a former rule of law no longer fits, courts are free to depart from precedent and create new rules. See, e.g., Kriske v. Hodge, 349 W.D. 384 (1961) (overruling the doctrine of parental immunity against suits by their minor children because the rule was "manifestly out of accord with modern 
conditions of life"); Laxney v. Hoover Community Schools, 448 W.D. 39 (1971) (overruling the doctrine of sovereign immunity for local school districts for similar reasons). However, there is nothing in the record of this case that suggests that the doctrine of corporate personhood is in any way "out of accord with modern conditions of life." Instead, the County argues that the Supreme Court, in the Santa Clara case, didn't really decide that corporations are entitled to the protections of the Fourteenth Amendment. The County supports this proposition by pointing out that the discussion of the property rights of corporations occurs in the court reporter's syllabus of that case, not in the Court's opinion itself. See Santa Clara, 118 U. S. at 396.

But even if this Court were to presume that the court reporter inaccurately reported Chief Justice Waite's remark that the Supreme Court was unanimously convinced that corporations do enjoy such protection, the County's argument fails to account for the numerous decisions, both of the United States Supreme Court and of many other courts (including this one), in which the Santa Clara case was cited with approval for this exact proposition. See, e.g., cases cited at p. 4, supra. Thus, even if Santa Clara were not good authority for this proposition, any one of the later cases which adopt that proposition can stand as good authority.

West Dakota stands with virtually every other jurisdiction in the country in holding that corporations enjoy the right to speak freely on matters of public concern. (A Westlaw search reveals court decisions in 30 states which include a holding that corporations are "persons" within the protection of the Fourteenth Amendment.) Since the corporate form of organization is central to the economic prosperity that all citizens benefit from, the County has a very heavy burden to show how corporate free speech rights are in any way "out of accord with modern conditions of life." It has failed to present any such evidence; accordingly, there is no justification for this Court to abandon this long-standing rule of law.

\section{The "self determination" provisions of the West Dakota Constitution do not conflict with corporate free speech rights}


The County's alternative argument is based upon a claim that governments are created by human persons, to serve human persons, and that allowing corporations to voice their opinions to those governments contravenes Article I, $§ 1$ of the West Dakota Constitution. However, the word "human" appears nowhere in that provision, and no reason exists to suppose that the drafters intended to so limit that provision.

West Dakota was admitted to the Union in 1904. The current Constitution of West Dakota, including Article I, $\S 1$ as it currently appears, was substantially rewritten in 1952 and ratified by the voters that same year. The Constitution of 1902 contained a substantially similar declaration that the Constitution was adopted "by and for the People, in the exercise of their indefeasible right to form a Government for their peace, safety and well-being." West Dakota Constitution of 1902, Article I, § 1 (repealed).

At both the time of the original 1902 Constitution and its revision in 1952, the corporate form of governance was well-known. Many key United States Supreme Court cases recognizing that corporations were "persons" entitled to the protections of the Fourteenth Amendment pre-dated the adoption of both West Dakota constitutions. See cases cited at p. 4, supra. Had the framers of those documents meant to limit the scope of these provisions to "human persons" as the County now claims, it would have been a simple matter to include the word "humans" in that provision. They did not include that word, however. Since the word "person" was well-understood even as long ago as 1902 to include corporations, this Court should continue to adhere to that interpretation.

\section{Conclusion}

Corporations have long enjoyed the right to freedom of speech to protect their interests. This is as it should be, since the First Amendment protects speech, not speakers. A robust "marketplace of ideas" is essential to the continued economic prosperity that all citizens, including those in Independence County, West Dakota, enjoy. Since Proposition 3 seeks to silence a broad category of potential speakers in that marketplace, it violates the First Amendment. Accordingly, this Court should reverse the court below and remand this case to the trial court with instructions to dismiss the Complaint in this case. 
Respectfully submitted

/s/ Attorney Two

Attorney Two, Esq.

413 Main Street

Old Orleans, W.D.

Counsel for Petitioner, BiggBox Lumber

Inc. 


\section{In The SuPREMe CoURT OF WeST DAKota}

Biggbox Lumber Company,

Inc., a Delaware corporation,

Petitioner

vS.

Independence County, a

political subdivision of the State of West

Dakota, by and through Charles

White, in his capacity as District

Attorney of Independence County,

Respondents

No. 421 G.D. 2008

On Petition for Review from the Court of Appeals of

West Dakota, opinion dated June 2, 2008, at

No. 802 of 2008

BRIEF ONE FOR RESPONDENT

Submitted by:

Attorney One, Esq.

314 Main Street

Old Orleans, W.D.

Counsel for Respondent, Independence

County 


\section{Table of Contents}

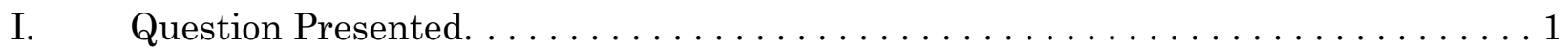

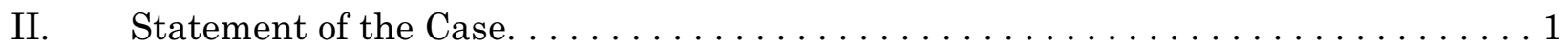

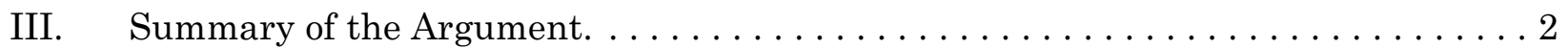

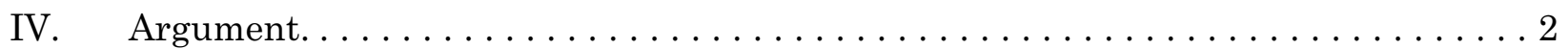

A. This Case is Controlled by State Law. . . . . . . . . . . . . . 3

1. Courts should, if possible, decide cases based upon narrow State-law grounds before reaching federal issues. . . . . . . . . . . 3

2. The West Dakota Constitution's declaration of human rights is an adequate State-law basis for deciding this case. . . . . . . . . . 4

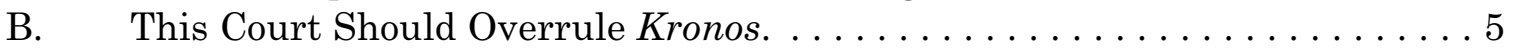

1. The Santa Clara decision did not consider whether, nor decide that, corporations are "persons". ................. 6

2. The doctrine of corporate personhood conflicts with the West Dakota

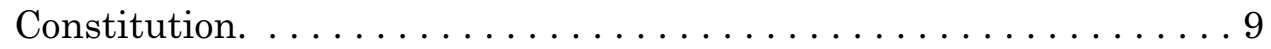

3. The doctrine of corporate personhood is untenable in today's world

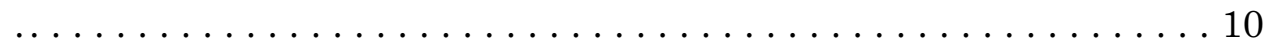

C. The Rights of Humans Are Superior to the "Rights" of Corporations. . . . . 13

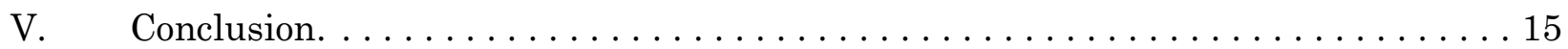




\section{Table of Authorities}

\section{Constitutional Provisions}

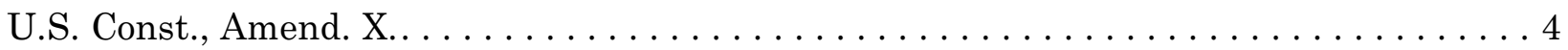

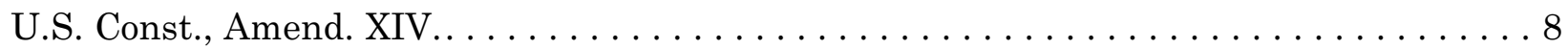

W.D. Const., Art. I, $\S 1 . \ldots \ldots \ldots \ldots \ldots \ldots \ldots \ldots \ldots \ldots$. $\ldots \ldots \ldots$. $13-15$

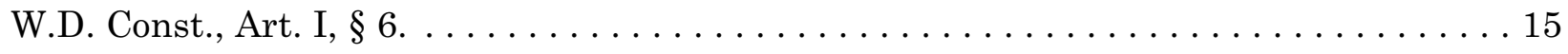

\section{Statutory Provisions}

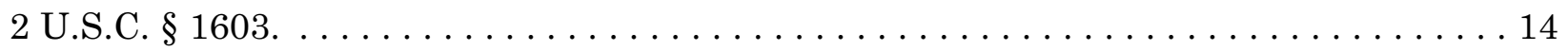

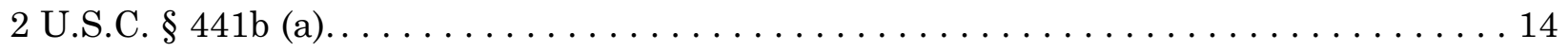

Independence County Proposition $3, \S 5(2003) \ldots \ldots \ldots \ldots \ldots \ldots \ldots \ldots$

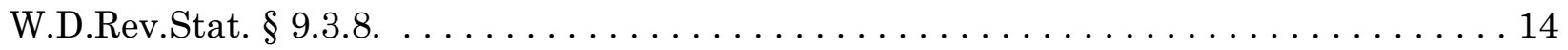

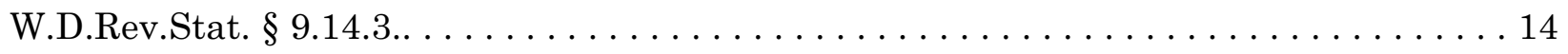

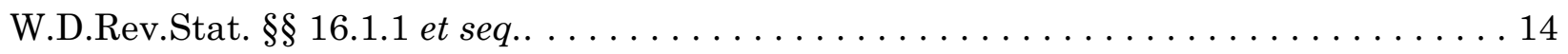

W.D.Rev.Stat. $\S 16.13 .2 \ldots \ldots \ldots \ldots \ldots \ldots \ldots \ldots \ldots \ldots \ldots \ldots \ldots \ldots \ldots \ldots$

\section{Cases}

Bandero v. City of New Bern, 728 F.2d 539 (13th Cir.1985). . . . . . . . . . . . . . . 4

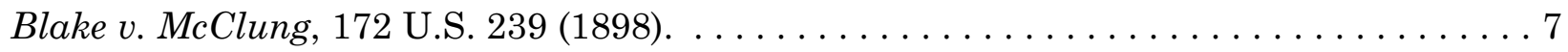

Brown v. Board of Education, 347 U.S. $483(1954) \ldots \ldots \ldots \ldots \ldots \ldots \ldots \ldots \ldots$

Covington \& L. Turnpike Road Co. v. Sandford, 164 U.S. 578 (1896). . . . . . . . . . . 7

Furman v. St. Vincent Hospital, 479 W.D. $368(1965) \ldots \ldots \ldots \ldots \ldots \ldots \ldots$

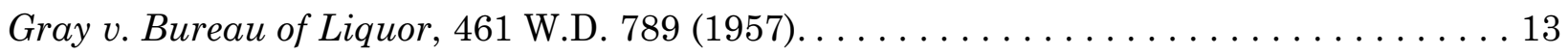


Insurance Company v. New Orleans, 1 Woods 85, 13 F. Cas. 67 (1871). . . . . . . . . . . 8

Jefferson v. City of Old Orleans, 23 F.3d 135 (13th Cir.1993). . . . . . . . . . . . . . 3

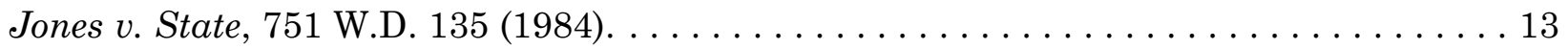

Kentucky Finance Corp. v. Paramount Auto Exchange Corp., 262 U.S. 544 (1923). . . . . . 7

Kronos Timepieces, Inc. v. Serafin, 451 W.D.469 (1962). . . . . . . . . . . . . 5, 6, 9, 12

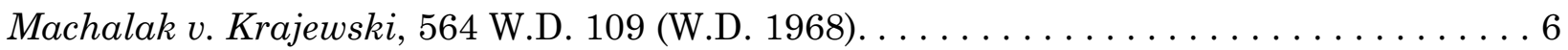

Santa Clara Co. v. Southern Pac. Ry. Co., 118 U. S. 394 (1886). . . . . . . . . . 6, 7, 9, 15

State $v$. Miller, 423 W.D. $675(1952) \ldots \ldots \ldots \ldots \ldots \ldots \ldots \ldots \ldots \ldots \ldots \ldots \ldots \ldots$

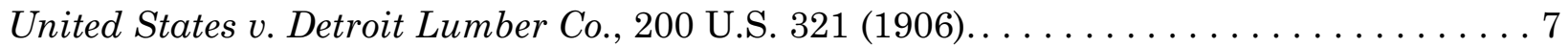

Wheeling Steel Corp. v. Glander, 337 U.S. $562(1949) \ldots \ldots \ldots \ldots \ldots \ldots \ldots \ldots \ldots$

\section{Secondary Authorities}

Bernhard Knollenberg, Growth of the American Revolution, 1766-1775 (1975). . . . . . . 12

Cardozo, The Nature of the Judicial Process (Yale University Press 1921). . . . . . . . . 10

Hurst, The Legitimacy of the Business Corporation in the Law of the United States, 1780-

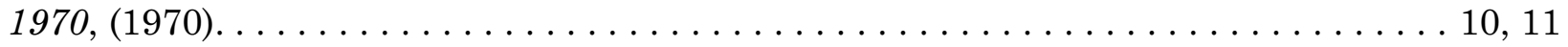

Mayer, Personalizing the Impersonal: Corporations and the Bill of Rights, 41 Hastings L.J.

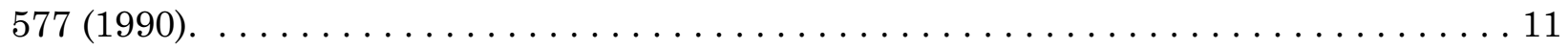

State to Offer Tax Subsidies for New Plant, Old Orleans Gazette, March 15, 2007. . . . . 12

Thomas Jefferson, The Jeffersonian Cyclopedia: A Comprehensive Collection of the Views of Thomas Jefferson (Foley, Ed.; Funk and Wagnalls 1900). . . . . . . . . . . . . . . . . 12 


\section{Question Presented}

The question certified by this Court is as follows: "Whether Proposition 3, adopted by the voters of Independence County, unconstitutionally deprives corporations of protectable rights under either the First Amendment to the United States Constitution or Article $1, \S 6$ of the West Dakota Constitution."

\section{Statement of the Case}

In November 2003, the voters of Independence County, West Dakota, adopted Proposition 3. Section 5 of that initiative prohibits "non-local corporations" from using corporate funds to, among other things, "[i]nfluenc[e] public opinion in an effort to promote or defeat any ordinance, resolution, or initiative, or any amendment thereto, under consideration by Independence County or any local government unit within Independence County ....".

The Petitioner, BiggBox Lumber Company, Inc. ("BiggBox"), has acquired an option to purchase 100 acres of vacant land in Wetmarsh Township, Independence County, near the interchange of Highway 81 and County Road BB. In the summer of 2007 it petitioned the Wetmarsh Township supervisors to rezone that tract to C-1 Commercial to allow it to build a BiggBox SuperCenter retail store. On August 1, 2007, BiggBox took out a full-page ad in the Old Orleans Gazette, urging citizens of Wetmarsh Township to write to their supervisors to support the zoning change.

On August 21, 2007, the township supervisors rejected the rezoning request, and

sent a letter to the Independence County District Attorney, pointing out that BiggBox's ad in the Old Orleans Gazette violated section 5 of Proposition 3. The District Attorney then brought this lawsuit seeking to impose the fine required by Section 11 of Proposition 3. BiggBox moved to dismiss the Complaint on several grounds, including a claim that Proposition 3 was an unconstitutional violation of BiggBox's right of free speech.

The Superior Court of Independence County ruled on November 12, 2007 that Proposition 3 violated the First Amendment to the United States Constitution, and dismissed the Complaint without addressing BiggBox's other claims. On appeal the Court 
of Appeals of West Dakota reversed and remanded the case for consideration of BiggBox's other claims. BiggBox petitioned this Court for review of the ruling by the court below, which this Court granted on July 28, 2008, limited to the issue specified above.

\section{Summary of the Argument}

Where an adequate rule of decision exists based on state law, courts should endeavor to resolve the question on that basis rather than reach the federal law question. Here, the declaration of the people's right to life, liberty and pursuit of happiness, guaranteed by the West Dakota Constitution, fully supports Proposition 3.

The Free Speech Clause of the First Amendment to the United States Constitution does not "trump" the West Dakota constitutional protections of citizen's rights. Corporations are not, or at least should not be, "persons" for the purpose of Fourteenth Amendment analysis (or for First Amendment protections applicable to the states through the Fourteenth Amendment). Prior cases of the United States Supreme Court which suggest that corporations are "persons" protected by the Fourteenth Amendment proceed from an unexamined assumption in the case of Santa Clara County v. Southern Pacific Railway, 118 U. S. 394 (1886). That case, in fact, is contradicted by a prior ruling of the United States Supreme Court, which has never been overruled by that Court.

\section{Argument}

In November, 2003 the voters of Independence County adopted Proposition 3, which provides in relevant part:

\section{Section 5. Prohibitions.}

Non-local corporations shall be prohibited from paying or contributing, directly or indirectly, any money, property, compensated service of its officers or employees, independent expenditures, or any other thing of value for the purpose of:

c) Influencing public opinion in an effort to promote or defeat any ordinance, resolution, or initiative, or any amendment thereto, under 
consideration by Independence County or any local government unit within Independence County.

Independence County Proposition 3, § 5 (adopted November, 2003, effective January 1, 2004).

BiggBox challenges this provision on the ground that it violates BiggBox's claimed right of free speech. Indeed, this Court has said, on several occasions, that corporations enjoy rights under both the First Amendment to the United States Constitution, and the free speech provisions of the West Dakota constitution, on nearly an equal footing with human beings. This Court should now either overrule those cases directly, or at least limit those precedents in such a way that they do not conflict with Article I, section 1 of the West Dakota Constitution, which gives all citizens of the state the right to self-determination.

\section{A. This Case is Controlled by State Law}

The Petitioner, in its Brief, argues that this case is controlled by the First Amendment to the United States Constitution, as applied to the states through the Fourteenth Amendment. It also relies upon various United States Supreme Court cases, many of them quite old, which purport to recognize that corporations have certain liberty interests protected by the Fourteenth Amendment.

While Respondent will show in part B of this Argument that those Supreme Court authorities are built upon a faulty premise, this Court need not address these claims. Federal courts should not go out of their way to decide broad questions of federal Constitutional dimension when an adequate state-law ground for decision exists; a fortiori state courts should likewise decide cases on state law wherever possible. In this case, a valid provision of the West Dakota Constitution provides an adequate basis for decision, such that the federal Constitutional grounds need not be reached.

\section{Courts should, if possible, decide cases based upon narrow State-law grounds before reaching federal issues \\ Federal courts have uniformly held that they "should avoid adjudication of federal} constitutional claims when alternative state grounds are available." Jefferson v. City of Old Orleans, 23 F.3d 135 (13th Cir.1993). Further, "[w]here the state constitutional provisions 
offer more expansive protection than the federal constitution, [the Court] must address the state constitutional claims in order to avoid unnecessary consideration of the federal constitutional claims." Id. at 139. Thus, "[i]f the West Dakota Constitution provides 'independent support' for [Respondent's] claims, then 'there is no need for decision of the federal [constitutional] issue.'” Bandero v. City of New Bern, 728 F.2d 539 (13th Cir.1985).

If federal courts are required to decide cases based upon appropriate State constitutional provisions, a fortiori the courts of this state should also decide cases in the same manner. West Dakota courts draw upon both state and federal law for their state constitutional analyses. See Smith v. Westfield Commons, Inc., 763 W.D. 567 (1984). "Federal principles are relevant but not conclusive so long as federal rights are protected." Wallis v. Eagle Preserve, Inc., 617 W.D. 541 (1976). "[W] here state law affords greater protection to expression of free speech than federal law, state law prevails." Id. at 545.

\section{The West Dakota Constitution's declaration of human rights is an adequate State-law basis for deciding this case}

Article I, $\S 1$ of the West Dakota Constitution provides:

\section{$\S 1$ - Inalienable rights}

We the People declare that all People are created equal; that they are endowed by their Creator with certain inalienable rights; that among these are life, liberty, and the pursuit of happiness; that all power is inherent in the People; and that all free governments are, and of right ought to be, founded on their authority, and instituted for their peace, safety, and well-being. For the advancement of these ends, the People have, at all times, an indefeasible right to alter and reform their government.

W.D. Const., Art. I, $§ 1$. These fundamental rights do not contravene any part of the United States Constitution; to the contrary, that document expressly reserves to the States and to "the people" all rights not expressly delegated to the federal government, nor prohibited to the states. U.S. Const., Amend. X. The right of the people "to alter and reform their government," as well as their "inalienable rights" of "life, liberty and the pursuit of happiness," protected by Article, I, § 1 of the West Dakota Constitution, are completely consistent with the United States Constitution. 
Part C of this brief will demonstrate that Article I, $\S 1$ of the West Dakota

Constitution protects the right of humans to self-determination, and that humans therefore have the right to limit the power of corporations to attempt to override the decisions made by those human citizens. It is sufficient for present purposes merely to observe that this provision of the West Dakota constitution is an "alternative state ground" that provides "more expansive protection" of individual rights than does the United States Constitution, and therefore should provide the basis for decision in this case.

\section{B. This Court Should Overrule Kronos}

The first express recognition in West Dakota of corporate liberty interests was in the case of Kronos Timepieces, Inc. v. Serafin, 451 W.D.469 (1962). In that case, the plaintiff corporation (which had been incorporated in Delaware but which did business in West Dakota) challenged, on Equal Protection and Commerce Clause grounds, a provision of the West Dakota Sales and Use Tax Act, which it claimed required West Dakota customers to pay a higher amount in a "use tax" from out-of-state vendors than they would pay in sales tax from West Dakota vendors. The state claimed that the corporation lacked standing to challenge the provision because it was not a "person" for the purposes of Equal Protection analysis. The state further claimed that it was not bound by the various rulings of the United States Supreme Court to the contrary, discussed in the next section, because corporations are creations of state law, and therefore invested only with those legal attributes assigned to them by the state. This Court, however, reversed, holding that the interpretation of the United States Constitution, and specifically the $14^{\text {th }}$ Amendment thereto, is the exclusive province of the United States Supreme Court. Id. at 473.

Respondent is mindful of the rule of stare decisis and the great reluctance of courts to depart from settled law. However, as this court said in Machalak v. Krajewski, 564 W.D. 109 (1968), "stare decisis is not an inflexible rule requiring this court to blindly follow precedents and adhere to prior decisions ...". This Court recognized that "when it appears that public policy and social needs require a departure from prior decisions, it is our duty as a court of last resort to overrule those decisions and establish a rule consonant with our present day concepts of right and justice." Id. at 112. Given the mischief that unrestrained 
corporate speech has occasioned in the marketplace of ideas, it is time for this Court to reconsider Kronos in light of "present day concepts of right and justice."

\section{The Santa Clara decision did not consider whether, nor decide that, corporations are "persons" \\ Most court decisions, and commentators, trace the origin of the "corporate}

personhood" doctrine to the case of Santa Clara Co. v. Southern Pac. Ry. Co., 118 U. S. 394 (1886). Indeed, this court cited Santa Clara in its decision in Kronos. 451 W.D. at 473. In Santa Clara, the Supreme Court was faced with the issue of whether local taxes had been properly levied on fences owned by several railroad companies. The court reporter's syllabus of the case indicates that, at oral argument, the Chief Justice said that the Court did not want to hear argument on the question of whether the railroad corporations were "persons" for the purpose of the Equal Protection Clause, stating that it was of the unanimous opinion that the clause did protect those corporations. Id. at 396. The entire reported opinion is devoted to a discussion of the issue of whether the fences were part of the "roadway" subject to taxation by the State of California, or merely "improvements" subject to taxation by local governments. The court found that the fences were subject only to local taxation, and that therefore the state's attempts to include the fences in the value of the "roadway" was improper. The court concluded, "As the judgment can be sustained upon this ground it is not necessary to consider any other questions raised by the pleadings and the facts found by the court." Id. at 416.

A court reporter's syllabus is not part of the court's opinion, and therefore it cannot be binding precedent. See United States v. Detroit Lumber Co., 200 U.S. 321 (1906). Moreover, even assuming that the reporter accurately recorded the remarks of the Chief Justice at oral argument, taken at face value the remarks say expressly that the Court would not "hear argument" on the issue. In essence, the Court was assuming (but not deciding) that corporations had a protectable liberty interest at stake.

It is remarkable that the Santa Clara case has become well-known not for what the Court itself actually wrote about the taxation of railroad property, but for the comment in the court reporter's syllabus regarding the assumption that corporations are "people." Yet the case has been cited regularly by subsequent courts for authority that corporations have 
the same legal rights as humans, with scant notice that the court's opinion specifically declined to answer any question beyond the authority to levy the tax on the facts of that case. See, e.g., Covington \& L. Turnpike Road Co. v. Sandford, 164 U.S. 578 (1896); Blake v. McClung, 172 U.S. 239 (1898); Kentucky Finance Corp. v. Paramount Auto Exchange Corp., 262 U.S. 544 (1923). Justice Jackson, writing separately in the case of Wheeling Steel Corp. v. Glander, 337 U.S. 562 (1949), did note that majority opinion in that case assumed, without discussing, that corporations are "persons" for the purpose of $14^{\text {th }}$ Amendment analysis. He noted, however, that the issue of what rights corporations held under the $14^{\text {th }}$ Amendment had been "appropriate for consideration" numerous times in prior cases, and in each case the court proceeded to address the merits of the corporations' claims. Id. at 575 .

The question of whether corporations are "persons" for the purpose of the Equal Protection Clause has, in fact, been addressed and ruled on directly by the United States Supreme Court. In Insurance Company v. New Orleans, 1 Woods 85, 13 F. Cas. 67 (1871), decided just three years after the $14^{\text {th }}$ Amendment was adopted, the Court had to decide whether a city ordinance which imposed a higher tax upon out-of-state corporations violated the Equal Protection Clause. The court analyzed the $14^{\text {th }}$ Amendment closely and held that "plain and evident meaning of the section is, that the persons to whom the equal protection of the law is secured are persons born or naturalized or endowed with life and liberty, and consequently natural and not artificial persons.” Id., 13 F. Cas. at 68. That case has never been overruled by the Supreme Court (although it has been cited with approval in two dissenting opinions).

The Court, in reaching this conclusion, reasoned not only from its knowledge of the then-recent enactment of the $14^{\text {th }}$ Amendment, but also directly from the words of that amendment. The first sentence of the amendment reads, "All persons born or naturalized in the United States, and subject to the jurisdiction thereof, are citizens of the United States and of the State wherein they reside." The court noted that "[o]nly natural persons can be born or naturalized ...”. Likewise, the court held that Due Process Clause, which prohibits states from depriving "any person of life, liberty or property" did not apply to corporations since "only natural persons can be deprived of life or liberty." Id. 
It would be odd, indeed, for the direct holding of the Supreme Court in Insurance Company to be "overruled" sub silentio not by a later decision of that Court, but by a court reporter's syllabus. Yet that is, in effect, what Biggbox argues in this case.

\section{The doctrine of corporate personhood conflicts with the West Dakota Constitution}

This Court's decision in Kronos relies upon the Santa Clara case as authority that corporations enjoy constitutional protection as "persons," without noting that the corporate personhood language is from the court reporter's syllabus and not the actual opinion. Kronos, 451 W.D. at 473. As this Court has held, however, a "court should not perpetrate error solely for the reason that a previous decision, even though based on an erroneous interpretation of the law, was rendered many years ago and has become settled law." Furman v. St. Vincent Hospital, 479 W.D. 368, 371 (1965) (overturning the doctrine of charitable immunity in tort based, in part, on a finding that the precedents cited in the original West Dakota cases adopting the doctrine cited old English cases which had later been repudiated by the English courts). In this case, the precedent cited by this Court in Kronos has not just been repudiated; it never existed in the first place (as shown in the previous section).

Since the "corporate personhood" doctrine originates from an unexamined, and unargued, assumption, this Court should now do what the Supreme Court failed to do in 1886: critically examine whether investing corporations with all of the rights of human beings makes logical sense, or is sound public policy.

At best, the doctrine of corporate personhood is a judicially-created concept. It must therefore yield to higher authority. In this case, Article I, § 1 of the West Dakota Constitution, which guarantees human rights, overrides the doctrine, as demonstrated in Part C below.

\section{The doctrine of corporate personhood is untenable in today's world}

As Justice Cardozo once wrote, "when a rule, after it has been duly tested by experience, has been found to be inconsistent with the sense of justice or with the social welfare, there should be less hesitation in frank avowal and full abandonment." Cardozo, 
The Nature of the Judicial Process, 150 (Yale University Press 1921). In determining the viability of a judicial doctrine, courts must consider the effect of that doctrine in the modern world. Brown v. Board of Education, 347 U.S. 483, 492-93 (1954).

At the time the Santa Clara decision was rendered, corporations were relatively weak and were subject to strict regulation by the states which chartered them. In the late eighteenth and early nineteenth century, the large majority of corporations chartered by states were limited-purpose corporations engaging in what might be considered "public utility" works today (transportation, including building roads and turnpikes; water systems; and some banks and insurance companies). Very few corporations before the 1830 's were general business corporations. Hurst, The Legitimacy of the Business Corporation in the Law of the United States, 1780-1970, 17-18 (1970). From about 1850 to 1880, the use of the corporate form for private business enterprises began to increase, first as a result of judicial interpretations that the corporate form provided limited liability for the owners, and later as states enacted limited liability provisions into their corporation laws. Id. at 27.

Some contemporary scholars of the mid-nineteenth century feared that the use of the corporate form for private business activities might subvert market control of private economic behavior. They feared that corporations would amass concentrations of assets that could overpower smaller economic actors. Id. at 43. These fears proved prescient. Since the mid-1800's (and to some extent as a result of the Santa Clara decision), corporations have amassed vast fortunes, successfully challenged a wide variety of legal regulations sought to be imposed on them by the states, and have successfully argued that most parts of the Bill of Rights applies to them. See generally Mayer, Personalizing the Impersonal: Corporations and the Bill of Rights, 41 Hastings L.J. 577 (1990).

The fact that corporations are now able to amass wealth and operate with little or no oversight by the government or even by their shareholders has led to the unrepentant exploitation of the environment, as well the humans that corporations were originally intended to serve. To some extent, the events of the recent months in the world of corporate finance are symptoms of how unrestrained corporate speech has allowed corporation to operate without sufficient oversight. 
Corporations are amoral; they exist only to make money. They do so by exploiting all resources available to them, natural and human. Corporations have no need or appreciation for beauty or aesthetics. They do not breathe, drink or eat, so they have no need for clean air, potable water or tillable soil. If raw materials can be obtained more cheaply by leaving behind pollution, the law of the market creates a powerful incentive for the corporation to do so, since it will not suffer the consequences of that pollution. If a product can be made more cheaply by employing workers in distant lands who lack the protection of American labor laws, the market again creates powerful incentives to manufacture those products in those lands, leaving American workers jobless.

Corporations have even used the threat of moving industrial plants, or locating new plants, in order to win tax reductions and other forms of state subsidies. See, e.g., State to Offer Tax Subsidies for New Plant, Old Orleans Gazette, p. 1, col 1, March 15, 2007. In this way, corporations no longer serve the public, but view the public fisc as just another resource to be exploited in order to maximize their competitive advantages in the marketplace.

All of these things are possible only because corporations now enjoy protections under the Bill of Rights, despite the fact that the early colonists who adopted the Bill of Rights feared corporations and did not intend to facilitate this new form of domination. The Boston Tea Party, for example, was an act of rebellion not only against the King of England, but also against the East India Company, a corporation chartered by the British government. Bernhard Knollenberg, Growth of the American Revolution, 1766-1775, 90 (1975). As Thomas Jefferson later wrote, "I hope we shall . . crush in its birth the aristocracy of our moneyed corporations, which dare already to challenge our government to a trial of strength and bid defiance to the laws of our country." Thomas Jefferson, The Jeffersonian Cyclopedia: A Comprehensive Collection of the Views of Thomas Jefferson, 49 (Foley, Ed.; Funk and Wagnalls 1900).

Humans need more than money to survive and to enjoy life. Corporations, which were created by humans to serve humans, should not be permitted to use the rights granted to humans to deprive humans of their natural rights to life, liberty and the pursuit 
of happiness. For this reason, the doctrine of corporate personhood, adopted in this state in the Kronos case, no longer fits the modern world. At a minimum, however, corporate rights should be held to be subordinate to the greater right of the People of the State of West Dakota to create, alter, or reform their government, a right guaranteed by Article I, $\S 1$ of the West Dakota Constitution.

\section{The Rights of Humans Are Superior to the "Rights" of Corporations}

As noted above, the West Dakota Constitution defines "life, liberty, and the pursuit of happiness" as "inalienable rights" belonging to the People. W.D. Const., Article I, § 1. There are no reported cases in West Dakota in which any corporate entity has attempted to assert protection under this provision, probably because "life, liberty and the pursuit of happiness" are human attributes, wholly inapplicable to the artificial form of corporate organization.

All of the reported cases in which Article I, $\S 1$ has been invoked involve claims in which humans have attempted to assert liberty interests as defenses against government regulation. See, e.g., Gray v. Bureau of Liquor, 461 W.D. 789 (1957) (state laws which protect the public by regulating the sale and consumption of liquor do not violate this provision); Jones $v$. State, 751 W.D. 135 (1984) (parole laws are a valid exercise of the police power of the state and do not illegally impinge on the liberty interest protected under this provision); State v. Miller, 423 W.D. 675 (1952) (Article I, § 1 embraces the right of man to be free in enjoyment of faculties with which he has been endowed by his Creator, subject only to such restraints as are necessary for the common welfare; state law requiring photographers to obtain a license to practice photography violates this provision).

Not only do corporations have no rights under Article I, § 1 of the West Dakota Constitution, by statute they are subject to oversight, and possible termination of their corporate existence, by the Attorney General of West Dakota. W.D.Rev.Stat. $§ 16.13 .2$. Corporations exist (are "created”) by legislative permission; W.D.Rev.Stat. $\S \S 16.1 .1$ et seq.

Both Congress and the West Dakota legislature have recognized the ill effects that unlimited corporate participation in human political processes can have. All corporations 
are prohibited from making direct campaign contributions in elections to federal offices. 2 U.S.C. $§ 441 b$ (a). Likewise, corporations are prohibited from direct campaign contributions in state and local elections. W.D.Rev.Stat. § 9.3.8. Lobbyists employed by corporations (and others) must register with the Secretary of the Senate and the Clerk of the House of Representatives. 2 U.S.C. $§ 1603$. They must likewise register with the West Dakota Secretary of State. W.D. Rev. Stat. § 9.14.3. All of these provisions put corporations in their proper place: as limited servants of human needs.

The rights of humans, according to Article I, § 1, flow from "their Creator," while the rights of corporations are granted by humans through the agency of the state legislature and the West Dakota Corporations Law. Moreover, Article I, $§ 1$ reserves to the People the "indefeasible right to alter and reform their government;" a fortiori the People retain the right to alter and reform (i.e., control) corporations, which are created only because the government allows them.

For all of these reasons, the rights of humans guaranteed by the West Dakota Constitution are superior to the legislatively-granted "rights" of corporations. If "rights" asserted by corporations conflict with the natural rights of humans, the rights of humans must prevail.

Proposition 3 was adopted by the voters of Independence County by referendum. It is a direct exercise of their constitutional right to "alter or reform" their local government by forbidding corporations from seeking to influence the decisions of local government officials. Since the West Dakota Constitution grants the right to "alter or reform" government only to humans, Proposition 3 is constitutional.

\section{Conclusion}

This case, on the surface, presents a conflict between two provisions of the West Dakota Constitution: Article I, § 6 (guaranteeing freedom of speech) and Article I, $\S 1$ (safeguarding the right of the People to pursue life, liberty and happiness, as well as to alter and reform their government). At a more fundamental level, however, it presents a conflict between the rights of corporations and the rights of natural persons. 
The doctrine of corporate personhood has been erroneously attributed to the United States Supreme Court in the Santa Clara case. However, the court did not actually hear argument on that issue, and expressly declined to rule on any issue broader than the narrow question of which level of government had the right to tax railroad fences. This Court's own adoption of the corporate personhood doctrine, which relies on Santa Clara, should therefore be re-examined and discarded, since the far greater resources of corporate entities allows them to effectively drown out the voices of the people whom they supposedly serve.

Article I, $\S 1$ of the West Dakota Constitution affords corporations no relief. It acknowledges that humans have certain inalienable rights such as life, liberty and the pursuit of happiness, none of which can apply to artificial persons such as corporations. Since Proposition 3 was simply a direct exercise by the people of Independence County to "alter or reform" their government, it is constitutional.

Respectfully submitted

/s/ Attorney One

Attorney One, Esq.

314 Main Street

Old Orleans, W.D.

Counsel for Respondent, Independence County 


\title{
In The SuPREMe CoURT OF WeST DAKota
}

Biggbox Lumber Company,

Inc., a Delaware corporation,

\author{
Petitioner
}

vS.

Independence County, a

political subdivision of the State of West

Dakota, by and through Charles

White, in his capacity as District

Attorney of Independence County,

\section{Respondents}

No. 421 G.D. 2008

On Petition for Review from the Court of Appeals of

West Dakota, opinion dated June 2, 2008, at

No. 802 of 2008

\section{BRIEF TWO FOR RESPONDENT}

Submitted by:

Attorney Two, Esq.

413 Main Street

Old Orleans, W.D.

Counsel for Respondent, Independence

County 


\section{Table of Contents}

I. Question Presented. ............................. 1

II. Statement of the Case. . . . . . . . . . . . . . . . . . . 1

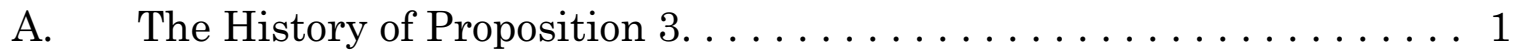

B. The Old Orleans Community. .................... 2

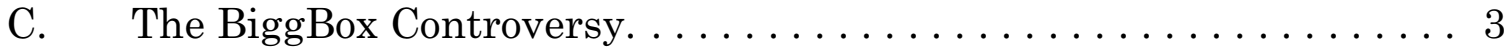

D. Procedural history...................... 4

III. Summary of the Argument. . . . . . . . . . . . . . . . . . 4

IV. Argument. .......................... 5

A. Proposition 3 Protects Independence County's Right to SelfDetermination, Guaranteed by the West Dakota Constitution... . . . . 6

B. This Court's Prior Rulings Granting Corporations Free Speech Protection Should Be Overruled. . . . . . . . . . . . . . . . 9

C. Affirming Proposition 3 Promotes the Values Protected By the West

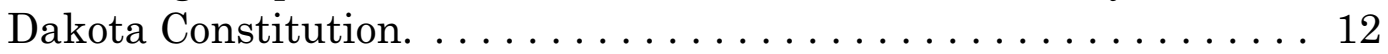

V. Conclusion............................... 13 


\section{Table of Authorities}

\section{Constitutional Provisions}

U.S. Const., Amend. X.. . . . . . . . . . . . . . . . . . . . . . . . . 7

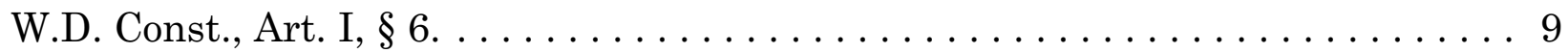

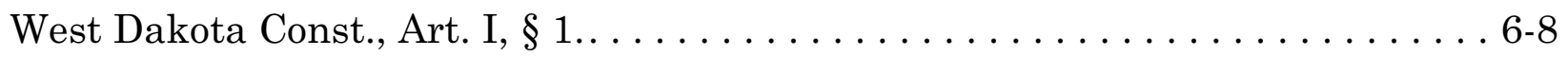

\section{Statutory Provisions}

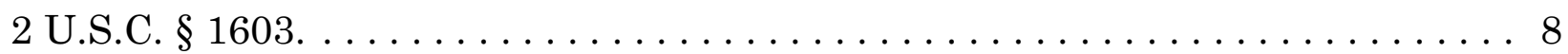

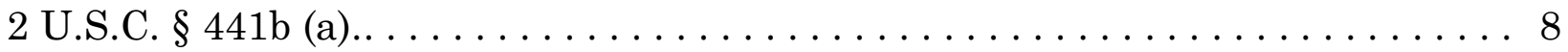

Independence County Proposition $3, \S 5(2003) \ldots \ldots \ldots \ldots \ldots \ldots \ldots \ldots \ldots \ldots$

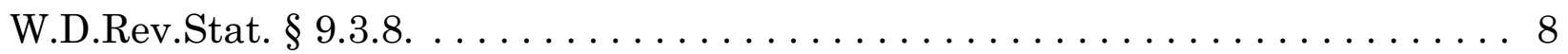

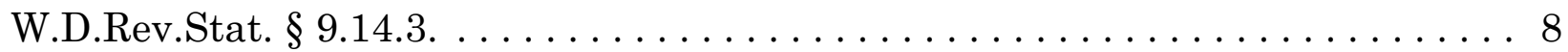

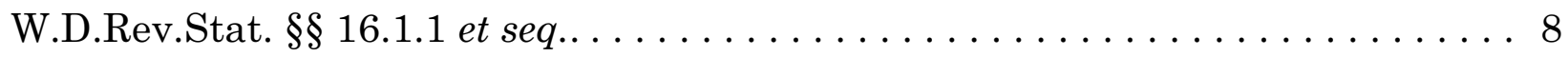

W.D.Rev.Stat. $\S 16.13 .2 \ldots \ldots \ldots \ldots \ldots \ldots \ldots \ldots \ldots \ldots \ldots \ldots \ldots \ldots \ldots \ldots 8$

\section{Cases}

Furman v. St. Vincent Hospital, 479 W.D. 368 (1965). . . . . . . . . . . . . 11

Gray v. Bureau of Liquor, 461 W.D. $789(1957) \ldots \ldots \ldots \ldots \ldots \ldots \ldots \ldots \ldots$

Insurance Company v. New Orleans, 1 Woods 85, 13 F. Cas. 67 (1871)... . . . . . 11

Jones $v$. State, 751 W.D. $135(1984) \ldots \ldots \ldots \ldots \ldots \ldots \ldots \ldots \ldots \ldots \ldots \ldots$

Kronos Timepieces, Inc. v. Serafin, 451 W.D.469 (1962). . . . . . . . . . . 9 9, 10 
Santa Clara Co. v. Southern Pac. Ry. Co., 118 U. S. 394 (1886).. . . . . . . . 10, 11

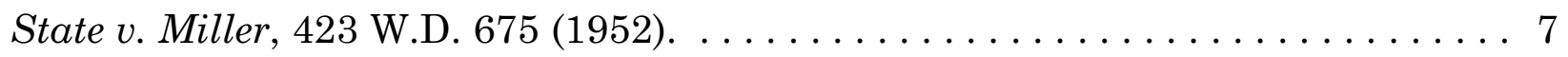

United States v. Detroit Lumber Co., 200 U.S. 321 (1906). . . . . . . . . . . . 10

\section{Secondary Authorities}

Food and Agriculture Organization of the United Nations, "Deforestation causes global warming," http://www.fao.org/newsroom/en/news/2006/1000385/index.html.12 


\section{Question Presented}

The question certified by this Court is as follows: "Whether Proposition 3, adopted by the voters of Independence County, unconstitutionally deprives corporations of protectable rights under either the First Amendment to the United States Constitution or Article 1, § 6 of the West Dakota Constitution."

\section{Statement of the Case}

\section{A. The History of Proposition 3}

The Lost River Valley has been described by the Natural World Conservancy of America as "one of the top ten unspoiled wildernesses left in America." It is home to the Lost River Valley Recreation Area, and is part of the nearly 800,000-acre Lost River National Forest. More than two-thirds of the national forest is located within Independence County, with the remainder in Washington County, West Dakota.

Maximus Lumber company, headquartered in Oregon but wholly owned by

Maximus World Enterprises, a multi-national corporation headquartered in the Netherlands, leases the logging rights to about 300,000 acres of the Lost River National Forest. In the summer and fall of 2001, the company sought an exemption from the West Dakota Department of Environmental Resources from a regulation that prohibited clear-cutting of any section of state forest lands, as well as a waiver of another regulation that limited the rate at which it could harvest lumber. The DER denied this request, and Maximus' attempt to persuade the state legislature to intervene failed by only two votes in the West Dakota House of Representatives.

Maximus Lumber then embarked on a public relations campaign and funded a statewide ballot initiative seeking to repeal the regulations. The company promoted itself as a "responsible forest management company" and claiming that many new lumber industry jobs and economic opportunities would flow from the increased availability of fresh timber in the area. 
A citizens group headquartered in Independence County, Save Our Forest Trees ("SOFT") raised and spent nearly $\$ 350,000$ in a campaign to defeat the initiative, which was defeated in November of 2001 by a statewide vote of $51 \%$ to $49 \%$. Within Independence County, the measure was defeated by a margin of $89 \%$ to $11 \%$.

Soon after that initiative was defeated, members of SOFT organized a grassroots effort to adopt a measure to prohibit distant corporations from participating in local political issues in the way that Maximus had done. As a direct result of that effort, in November, 2003, Independence County voters adopted Proposition 3, by a margin of $61 \%$ to $39 \%$.

\section{B. The Old Orleans Community}

Old Orleans is the town nearest to the Lost River Recreational Area. While in its history it was home to a large sawmill and a vibrant logging industry, in more recent years it has become a tourist destination and an artistic community. The borough is the county seat of Independence county. It is the geographic center of, and the largest population center, in the Old Orleans Area Council of Governments, an organization comprised of the Borough of Old Orleans and three surrounding townships which engages in regional planning for the area.

Since 1990 the borough has lost an estimated 7,000 residents. Since 1998, the regional planning commission estimates that the region has lost nearly 2,000 manufacturing jobs, although due to increases in tourist-related businesses the overall job loss for the region is only about 1,000 over that period.

The OOACOG comprehensive regional plan adopted in 2006 noted that the region appears to be in transition from a "manufacturing economy" to a tourismbased economy. It noted the recent growth of the "artists community" in the borough of Old Orleans and the opening of several new hotels in the region, all near 
the Lost River Recreation Area. The plan specifically called for targeted efforts to "channel economic development efforts" into the tourism industry, and to make the area attractive to "creative individuals." To implement the regional plan, the borough of Old Orleans and the surrounding townships all adopted zoning ordinances which provide for most commercial properties in the region to be located within the borough limits, with the surrounding townships being zoned primarily for agricultural or residential uses.

Almost all of the remaining manufacturing or industrial jobs in the region are located within the Borough of Old Orleans, in an industrial park on the southeast side of the borough. Due to the recent decline in manufacturing jobs, however, more than one third of the structures in that park are now vacant and are deteriorating. The downtown commercial district remains relatively vibrant, however. About ten years ago, there had been a noticeable decline in commercial activity downtown, with numerous vacant storefronts appearing. In the past three or four years, many of those vacant storefronts have been replaced with art galleries, craft shops, restaurants, or other stores catering to tourists and the growing artist community.

The largest remaining vacant property in the borough of Old Orleans is a former sawmill near downtown, which closed in 1988. Despite the fact that returning the site to economic productivity is consistent with the regional land use plan, efforts to redevelop the site have been unsuccessful to date.

\section{The BiggBox Controversy}

In early 2007, BiggBox Lumber Company acquired an option to purchase a vacant tract of land in Wetmarsh Township, about five miles south of the downtown area of Old Orleans. The land is near an interchange of Highway 81, the main highway into the Lost River Recreation Area. Since the land is currently zoned AR- 
1 Agricultural, BiggBox applied to the township zoning board for a rezoning of the property to C-1 Commercial.

The Old Orleans Industrial Development Agency, which has been in charge of the efforts to redevelop the vacant sawmill site in the borough, then approached BiggBox in an attempt to show BiggBox that the site was large enough and needed no rezoning in order to accommodate BiggBox's needs. It also put together a favorable tax-free financing package and other incentives hoping to convince BiggBox to locate within the borough. However, BiggBox rejected these overtures and pursued its strategy to obtain a rezoning of the Wetmarsh property. Part of its strategy in seeking this goal was to purchase a full-page ad in the Old Orleans Gazette, the weekly newspaper in the region, seeking to persuade both the local residents and the Wetmarsh Township officials that the rezoning would be in the best economic interest of the township.

On August 1, 2007, the township supervisors rejected the rezoning request. They also directed the chairman of the Board of Supervisors to report to the Independence County District Attorney the fact that BiggBox had taken out the advertisement in the Gazette, in violation of Proposition 3.

\section{Procedural history}

The District Attorney brought this action seeking to impose a fine of $\$ 20,120$, being ten times the cost of the advertisement (which is the fine specified in Proposition 3). BiggBox moved to dismiss the Complaint on several grounds, including a claim that Proposition 3 was an unconstitutional violation of BiggBox's right of free speech.

The Superior Court of Independence County ruled on Nov. 12, 2007 that

Proposition 3 violated the First Amendment to the United States Constitution, and dismissed the Complaint without addressing BiggBox's other claims. On appeal the Court of Appeals of West Dakota reversed and remanded the case for consideration 
of BiggBox's other claims. BiggBox petitioned this Court for review of the ruling by the court below, which this Court granted on July 28, 2008, limited to the issue specified above.

\section{Summary of the Argument}

The citizens of Independence County have a very large stake in determining what kind of community they live in. They have resisted large corporations in the past, having recently fought a statewide initiative sponsored by a lumber company which sought to accelerate the rate of harvesting trees from the area's primary attraction, the Lost River National Forest. In doing so, however, they were simply seeking to enforce their natural, inalienable rights under the West Dakota Constitution, over the supposed "rights" of inanimate corporate structures which do not share their values.

While prior rulings of this Court suggest that corporations do, in fact, enjoy protection under the Fourteenth Amendment (and through that, the freedom of speech guaranteed by the First Amendment to the United States Constitution), the primary case relied upon by this Court never really decided that issue. Rather, a prior Supreme Court case directly held that corporations were not "persons" entitled to Fourteenth Amendment protection. That holding has never been overturned by the Supreme Court. This Court should therefore overrule Kronos Timepieces, Inc. v. Serafin, and hold that corporate rights must be held subservient to the natural rights of humans guaranteed by the West Dakota Constitution.

Proposition 3 is an attempt by humans to reclaim that which is rightfully

theirs. Corporations have no need of clean air or potable water. The West Dakota Constitution guarantees these things to all humans, by guaranteeing to each citizen the rights to life, liberty and the pursuit of happiness. Proposition 3 advances those goals by allowing only humans to participate in the political processes which protect those rights. 


\section{Argument}

"The unique special character of the small towns and rural areas in America is disappearing faster... and we're losing our sense of place."

-Ed McMahon, senior resident fellow at the Urban Land Institute (from an address to the Center for the Environment and Society at Washington College,

as reported in the Kent County News, Feb. 2, 2006)

The Old Orleans region, gateway to the Lost River Recreation Area and the Lost River National Forest, is struggling to preserve its "sense of place." Four municipalities, centering on the borough of Old Orleans, have engaged in joint regional planning in a conscious effort to preserve a central business district, while allowing the outlying communities to retain their agricultural and residential character. And, recognizing the outside pressures that are often brought to bear that tend to force homogenization of communities, the voters of Independence County, acting on their own initiative, adopted an ordinance expressly declaring their independence from outside corporate influences. Proposition 3, adopted by those voters, provides in relevant part:

\section{Section 5. Prohibitions.}

Non-local corporations shall be prohibited from paying or contributing, directly or indirectly, any money, property, compensated service of its officers or employees, independent expenditures, or any other thing of value for the purpose of:

c) Influencing public opinion in an effort to promote or defeat any ordinance, resolution, or initiative, or any amendment thereto, under consideration by Independence County or any local government unit within Independence County.

Independence County Proposition 3, § 5 (adopted November, 2003, effective January 1, 2004). 
That ordinance, adopted in 2003 as Proposition 3, seeks to limit participation in local political decisions to the humans directly affected by those decisions. This is not only a reasonable human instinct, but also one fully supported by the West Dakota Constitution. Moreover, this Court's prior decisions that suggest that corporations share free speech protection equally with humans have proceeded from a flawed understanding of United States Supreme Court precedents that appear to grant civil rights to corporate entities. Those decisions ought to be now overruled, and corporations should be restored to their rightful place as servants of humans, rather than their masters.

\section{A. Proposition 3 Protects Independence County's Right to Self- Determination, Guaranteed by the West Dakota Constitution Article I, $\S 1$ of the West Dakota Constitution provides:}

\section{$\S 1$ - Inalienable rights}

We the People declare that all People are created equal; that they are endowed by their Creator with certain inalienable rights; that among these are life, liberty, and the pursuit of happiness; that all power is inherent in the People; and that all free governments are, and of right ought to be, founded on their authority, and instituted for their peace, safety, and well-being. For the advancement of these ends, the People have, at all times, an indefeasible right to alter and reform their government.

W.D. Const., Art. I, § 1. These fundamental rights do not contravene any part of the United States Constitution; to the contrary, that document expressly reserves to the States and to "the people" all rights not expressly delegated to the federal government, nor prohibited to the states. U.S. Const., Amend. X. The right of the people "to alter and reform their government," as well as to defend their "inalienable rights" of "life, liberty and the pursuit of happiness," protected by Article, I, $\S 1$ of the West Dakota Constitution, are completely consistent with the United States Constitution. 
The placement of this guarantee in the very first section of the West Dakota Constitution suggests its primacy among the rights of West Dakota citizens. Corporations, being artificial creations, have no ability to enjoy"life, liberty and the pursuit of happiness;" these are uniquely human rights. The term "People," as used in Article I, $\S 1$, must therefore refer only to humans.

Indeed, all of the reported cases in which Article I, $\S 1$ has been invoked involve claims in which humans have attempted to assert liberty interests as defenses against government regulation. See, e.g., Gray v. Bureau of Liquor, 461 W.D. 789 (1957) (holding that state laws which protect the public by regulating the sale and consumption of liquor do not violate this provision); Jones v. State, 751 W.D. 135 (1984) (holding that parole laws are a valid exercise of the police power of the state and do not illegally impinge on the liberty interest protected under this provision); State v. Miller, 423 W.D. 675 (1952) (this provision embraces the right of man to be free in enjoyment of faculties with which he has been endowed by his Creator, subject only to such restraints as are necessary for the common welfare; state law requiring photographers to obtain a license to practice photography violates this provision).

Not only do corporations have no rights under Article I, $\S 1$ of the West Dakota Constitution, by statute they are subject to oversight, and possible termination of their corporate existence, by the Attorney General of West Dakota. W.D.Rev.Stat. § 16.13.2. Corporations exist (are "created") by legislative permission; W.D.Rev.Stat. $§ 16.1 .1$ et seq.

Corporations are created by humans, to serve the needs of humans. The rights of humans, according to Article I, $§ 1$, flow from "their Creator," while the rights of corporations are granted by humans through the agency of the state legislature and the West Dakota Corporations Law. Moreover, since Article I, § 1 reserves to the People the "indefeasible right to alter and reform their government," 
a fortiori the People retain the right to alter and reform (i.e., control) corporations, which are created by the government which is subservient to the People.

Both Congress and the West Dakota legislature have recognized the ill effects that unlimited corporate participation in human political processes can have. All corporations are prohibited from making direct campaign contributions in elections to federal offices. 2 U.S.C. $\S 441$ b (a). Likewise, corporations are prohibited from direct campaign contributions in state and local elections. W.D.Rev.Stat. § 9.3.8. Lobbyists employed by corporations (and others) must register with the Secretary of the Senate and the Clerk of the House of Representatives. 2 U.S.C. $\S 1603$. They must likewise register with the West Dakota Secretary of State. W.D. Rev. Stat. $\S 9.14 .3$. All of these provisions put corporations in their proper place: as limited servants of human needs.

Proposition 3 simply does more directly what the political campaign finance and lobbying laws attempt to do indirectly. It prevents corporations from using their accumulations of capital to overwhelm the processes by which humans govern themselves. Independence County citizens, by virtue of Article I, $\S 1$ of the West Dakota Constitution, have the right to determine what kind of community they will live in. Since those citizens will breathe the air, drink the water, and enjoy the scenery in ways that corporations cannot, Proposition 3 is a valid exercise of their rights under the West Dakota Constitution.

\section{B. This Court's Prior Rulings Granting Corporations Free Speech Protection Should Be Overruled}

The prior rulings of this Court which grant free speech rights to corporations

are based on an unexamined assumption in a nineteenth century decision by the United States Supreme Court that the Fourteenth Amendment's reference to "persons" also protects corporations. It is time to finally examine that claim, and reject it. 
This Court has previously granted to corporations the right to free speech under Article I, $\S 6$ of the West Dakota Constitution. In Kronos Timepieces, Inc. v. Serafin, 451 W.D.469 (1962), the plaintiff corporation (which had been incorporated in Delaware but which did business in West Dakota) challenged, on Equal Protection and Commerce Clause grounds, a provision of the West Dakota Sales and Use Tax Act, which it claimed required West Dakota customers to pay a higher amount in a "use tax" from out-of-state vendors than they would pay in sales tax from West Dakota vendors. The state claimed that the corporation lacked standing to challenge the provision because it was not a "person" for the purposes of Equal Protection analysis. The state further claimed that it was not bound by the various rulings of the United States Supreme Court to the contrary, because corporations are creations of state law, and therefore invested only with those legal attributes assigned to them by the state. This Court, however, reversed, holding that the interpretation of the United States Constitution, and specifically the $14^{\text {th }}$ Amendment thereto, is the exclusive province of the United States Supreme Court. Id. at 473 .

Most court decisions, and commentators, trace the origin of the "corporate personhood" doctrine to the case of Santa Clara Co. v. Southern Pac. Ry. Co., 118 U. S. 394 (1886). Indeed, much of this Court's rationale in Kronos is drawn from Santa Clara. Kronos, 451 W.D. at 473. In Santa Clara, the Supreme Court was faced with the issue of whether local taxes had been properly levied on fences owned by several railroad companies. The court reporter's syllabus of the case indicates that, at oral argument, the Chief Justice said that the Court did not want to hear argument on the question of whether the railroad corporations were "persons" for the purpose of the Equal Protection Clause, stating that it was of the unanimous opinion that the clause did protect those corporations. $I d$. at 396 . The entire reported opinion is devoted to a discussion of the issue of whether the fences were part of the "roadway" subject to taxation by the State of California, or merely "improvements" subject to 
taxation by local governments. The court found that the fences were subject only to local taxation, and that therefore the state's attempts to include the fences in the value of the "roadway" was improper. The court concluded, "As the judgment can be sustained upon this ground it is not necessary to consider any other questions raised by the pleadings and the facts found by the court." Id. at 416 .

A court reporter's syllabus is not part of the court's opinion, and therefore it cannot be binding precedent. See United States v. Detroit Lumber Co., 200 U.S. 321 (1906). Moreover, even assuming that the reporter accurately recorded the remarks of the Chief Justice at oral argument, taken at face value the remarks say expressly that the Court would not "hear argument" on the issue; in essence, that it was assuming (but not deciding) that corporations had a protectable liberty interest at stake.

It is remarkable that the Santa Clara case has become well-known not for what the Court itself actually wrote about the taxation of railroad property, but for the comment in the court reporter's syllabus regarding the assumption that corporations are "people." It is even more remarkable in light of the fact that the question of whether corporations are "persons" for the purpose of the Equal Protection Clause had previously been addressed and ruled on directly by the United States Supreme Court. In Insurance Company v. New Orleans, 1 Woods 85, 13 F. Cas. 67 (1871), decided just three years after the $14^{\text {th }}$ Amendment was adopted, the Court had to decide whether a city ordinance which imposed a higher tax upon out-of-state corporations violated the Equal Protection Clause. The court analyzed the $14^{\text {th }}$ Amendment closely and held that "plain and evident meaning of the section is, that the persons to whom the equal protection of the law is secured are persons born or naturalized or endowed with life and liberty, and consequently natural and not artificial persons." Id., 13 F. Cas. at 68.

It would be odd, indeed, for the direct holding of the Supreme Court in Insurance Company to be "overruled" sub silentio not by a later decision of that 
Court, but by a court reporter's syllabus. In fact, Insurance Company has never been overruled by that Court.

A rule originally based on an erroneous interpretation of the law should not be perpetrated merely because it was rendered many years ago and has become settled law. Furman v. St. Vincent Hospital, 479 W.D. 368, 371 (1965) (overturning the doctrine of charitable immunity in tort based, in part, on a finding that the precedents cited in the original West Dakota cases adopting the doctrine cited old English cases which had been repudiated by the English courts even before the doctrine was adopted in West Dakota). Likewise, since Kronos was derived from precedent that was questionable, at best, when rendered, Kronos should be oveturned.

\section{Affirming Proposition 3 Promotes the Values Protected By the West Dakota Constitution}

As mentioned earlier, corporations were created by humans as a tool to help

order their business dealings. To that extent, corporations are useful tools in human efforts to protect their "life, liberty and pursuit of happiness." W.D. Const., Art. I, § 1. But when corporations start to interfere with those rights, humans have the right to intervene and reclaim their natural rights.

The citizens of Independence County are well aware of how corporate

interests can come to interfere with their Constitutionally protected right to "life, liberty and pursuit of happiness." In 2001, a multinational corporation headquartered in another state attempted to persuade state officials to allow it to clear-cut certain stands of timber in the Lost River National Forest, and to increase the rate at which it harvested lumber from other areas. Had Maximus Lumber Company been successful in those efforts, one of the region's most important natural treasures, the forest canopy, would have been immeasurably damaged. 
The Lost River National Forest, which includes the Lost River Recreation Area, is not only a primary way in which citizens (from Independence County and far beyond) can "pursue happiness," in a very real sense it is a way in which citizens protect their right to life itself. By some estimates, 25 to 30 percent of the greenhouse gases thought to be responsible for global warming are caused by deforestation. Food and Agriculture Organization of the United Nations, "Deforestation causes global warming," http://www.fao.org/newsroom/en/news/2006/1000385/index.html (visited Dec. 17, 2008). The biological connection between plant life and animal life (plants creating oxygen and animals creating carbon dioxide) is also well known. All animals, humans included, need plant life in order to survive; corporations do not.

Humans, many of them Independence County citizens, were forced to raise $\$ 350,000$ in order to defeat a political initiative by a corporation that would have harmed the environment in which those humans live. It is highly likely that similar contests between the supposed "rights" of corporations to exploit the environment, and the natural rights of people who depend upon that environment to sustain a healthy life, will arise in the future. Proposition 3 is but one small way in which those citizens can protect themselves from having to fight such battles in the future. This Court should not deprive them of this tool.

\section{Conclusion}

There is little more important to a citizen than the character and wholesomeness of the place he chooses to inhabit. The West Dakota Constitution guarantees to all citizens the inalienable rights to life, liberty and the pursuit of happiness. These are all uniquely human traits that have no relevance to the artificial "people" we call corporations. 
Corporations were invented to serve humans, but they have grown to such size and have amassed such wealth that they can attempt drown out dissent. Proposition 3 is an attempt by humans to reassert their inalienable rights. It should be held to be constitutional.

Respectfully submitted

/s/ Attorney Two

Attorney Two, Esq.

413 Main Street

Old Orleans, W.D.

Counsel for Respondent, Independence County 